\title{
Keterampilan Menyimak pada Anak Usia Dini Melalui Metode Bercerita
}

\author{
Rena Mianawati ${ }^{1}$, Tuti Hayati ${ }^{2}$, Aam Kurnia ${ }^{3}$

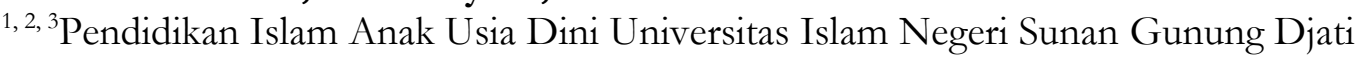 \\ Bandung \\ Jalan Soekarno Hatta Kel. Cimencrang, Gedebage Kota Bandung, Jawa Barat, Indonesia \\ Email:mianawatirena@gmail.com¹, hayatituti@yahoo.co.id², \\ kreatif_cemerlang@yahoo.co.id ${ }^{3}$
}

Naskah diterima: 29 Desember 2018, direvisi: 20 Maret 2019, diterbitkan: 30 Maret 2019

\begin{abstract}
Abstrak
Observasi awal yang dilakukan pada anak di kelompok B1 RA Persis 250 Cihamerang bahwa perkembangan bahasa anak belum optimal. Hal ini terbukti masih adanya hambatan anak yang belum mampu mempunyai keterampilan menyimak. Tujuan penelitian ini untuk mengetahui keterampilan menyimak anak sebelum dan sesudah diterapkan metode bercerita, dan penerapan mentode bercerita untuk meningkatkan keterampilan menyimak. Metode yang digunakan adalah Penelitian Tindakan Kelas (PTK) yang terdiri dari dua siklus Teknik pengumpulan data yang digunanakan ialah observasi, unjuk kerja, dan dokumentasi. Hasil penelitian menunjukkan bahwa keterampilan menyimak anak sebelum diterapkan metode bercerita diperoleh nilai 32,29 dengan kategori kurang sekali, sedangkan setelah diterapkan metode bercerita pada siklus I diperoleh nilai 52,71 dengan kategori kurang, siklus II diperoleh nilai 78,44 dengan kategori baik. Aktivitas guru saat diterapkan metode brcerita untuk meningkatkan keterampilan menyimak pada siklus I diperoleh rata-rata 71,88\% dengan kriteria cukup, dan pada siklus II diperoleh nilai rat-rata 90,63\% dengan kriteria sangat baik. Demikian pula hasil analisis aktivitas anak pada siklus I diperoleh nilai rata-rata 61,88\% dengan kriteria cukup, dan pada siklus II diperoleh nilai rata-rata 77,88\% dengan kriteria baik. Dengan demikian hipotesis yang diajukan diterima, artinya metode bercerita dapat meningkatkan keterampilan menyimak anak.
\end{abstract}

Kata kunci: keterampilan menyimak, metode bercerita, penelitian tindakan kelas 


\begin{abstract}
Preliminary observations were made on children in B1 $\mathrm{RA}$ Persis 250 Cihamerang group that children's language development was not optimal. This proved that there were still obstacles for children who were not able to have listening skills. The purpose of this study was to determine the listening skills of children before and after the storytelling method was applied, and the application of the storytelling method to improve listening skills. The method used is Class Action Research (CAR) which consists of two cycles. PTK methods include: planning, acting, observing, and reflecting. The data collection techniques used are observation, performance, and documentation. The results showed that the listening skills of children before the method of telling stories were obtained with 32.29 with very few categories, while after applying the method of telling stories to cyclic I obtained a value of 52.71 with a less category, the second cycle obtained a score of 78.44 with a good category. The application of the storytelling method to improve listening skills to teacher activities in the first cycle was obtained an average of $71.88 \%$ with sufficient criteria, and in the second cycle obtained an average value of $90.63 \%$ with very good criteria. Similarly, the results of the analysis of children's activities in the first cycle obtained an average value of $61.88 \%$ with sufficient criteria, and in the second cycle obtained an average value of $77.88 \%$ with good criteria. Thus the proposed hypothesis is accepted, meaning that the storytelling method can improve children's listening skills.
\end{abstract}

Keywords: classroom action research, listening skill, storytelling method

\title{
Pendahuluan
}

Pendidikan Anak Usia Dini (PAUD) adalah suatu upaya pembinaan yang ditujukan kepada anak sejak lahir dengan usia enam tahun, dilakukan melalui pemberian rangsangan untuk membantu pertumbuhan dan perkembangan jasmani dan rohani agar anak memiliki kesiapan dan keterampila dalam memasuki pendidikan lebih lanjut. Pendidikan anak usia dini merupakan salah satu bentuk penyelenggaraan pendidikan yang menitikberatkan pada peletakan dasar ke arah pertumbuhan dan perkembangan. Pertumbuhan dan perkembangan itu diantarannya perkembangan fisik (koordinasi motorik kasar dan halus), kecerdasan (daya pikir, daya cipta, kecerdasan emosi, dan kecerdasan spiritual), sosio emosional (sikap dan perilaku serta beragama), bahasa dan komunikasi, sesuai dengan keunikan dan tahap-tahap perkembangan yang dilalui oleh anak usia dini (Sujiono, 2013).

Menurut Dhienie (2008) perkembangan bahasa merupakan salah satu aspek yang harus dikembangkan, karena bahasa dipelajari dan diperoleh anak usia dini secara alami untuk beradaptasi dengan lingkungannya. Bahasa merupakan sarana komunikasi dengan orang lain, 
untuk menyatakan pikiran dan perasaan kepada orang lain. Perkembangan bahasa terdiri dari tiga lingkup, yaitu: menerima bahasa, mengungkapkan bahasa, dan keaksaraan. Salah satu kemampuan dari menerima dan mengungkapkan bahasa ialah kamampuan menyimak (Latifah, 2011).

Keterampilan menyimak merupakan keterampilan bahasa yang termasuk dalam bahasa reseptif, artinya keterampilan yang harus dikuasai oleh anak sebagai dasar keterampilan berbahasa yang lain. Dalam Permendiknas No.58 keterampilan menyimak yang seharusnya sudah dikuasai anak usia 4-5 tahun meliputi menyimak perkataan orang, memahami cerita yang dibacakan, dan menceritakan kembali cerita yang pernah didengar.

Menurut Iskandarwassid, dkk. (2011) keterampilan menyimak adalah satu bentuk keterampilan yang bersifat reseptif, artinya bukan sekedar mendengarkan bunyi-bunyi bahasa melainkan sekaligus memahaminnya. Sedangkan menurut Tarigan (2015) bahwa menyimak adalah proses mendengarkan lambang-lambang lisan dengan penuh perhatian, pemahaman apresiasi, serta interpretasi untuk memperoleh informasi, menangkap isi atau pesan serta memahami makna komunikasi yang disampaikan oleh pembicara melalui ujaran.

Berdasarkan pengertian di atas dapat disimpulkan bahwa keterampilan menyimak merupakan proses mendengarkan lambang-lambang lisan untuk memperoleh pemahaman informasi, komunikasi dan pesan yang disampaikan oleh pembicara. Menyimak merupakan proses mendengarkan penuh perhatian, pemahaman, apresiasi serta interpretasi untuk menangkap isi atau pesan serta memahami makna yang terkandung di dalamnya.

Hasil observasi awal di kelompok B1 RA Persis 250 Cihamerang Banjaran Kabupaten Bandung ditemukan permasalahan perkembangan bahasa, bahwa terdapat 5 anak dari 20 anak yang mengalami kesulitan dalam kemampuan bahasa sehingga keterampilan menyimak anak rendah. Pada umunya anak tidak memperhatikan dan tidak mendengarkan guru sehingga proses pembelajaran tidak berjalan optimal. Beberapa anak ada yang bermain dan mengobrol dengan temannya. Selain itu kegiatan yang dilakukan lebih kepada pemberian tugas seperti mewarnai dan menempel sementara latihan untuk menyimak tidak dikembangkan.

Berbagai metode dilakukan untuk mengembangkan kemampuan bahasa anak agar keterampilan menyimak anak dapat berkembang. Salah satu metode yang dapat membuat anak aktif dan senang yaitu dengan menggunakan metode bercerita. Metode bercerita merupakan salah satu pemberian pengalaman belajar secara lisan yang menarik, diantarannya anak dapat menjawab pertanyaan dari guru dan dapat menceritakan kembali isi cerita. 
Metode bercerita menurut Moeslichatoen (2004) sebagai salah satu pemberian pengalaman belajar bagi anak usia dini dengan membawakan cerita secara lisan. Sedangkan menurut Gunarti (2008) yang mengemukakan bahwa metode bercerita adalah salah satu metode dalam aspek pengembangan bahasa yang bertujuan untuk meningkatkan keterampilan menyimak, karena melalui metode bercerita anak bisa bercerita bebas dan mengemukakan ide-idenya, menyampaikan informasi, mempunyai daya tarik anak yang menyentuh persaan anak dan memahami pesan yang bisa dilakukan secara lisan atau tertulis.

Dari pendapat di atas dapat disimpulkan bahwa metode bercerita merupakan cara penyampaian atau penyajian materi pembelajaran secara lisan dalam bentuk cerita dari guru kepada anak. Metode bercerita merupakan metode pemberian pengalaman belajar yang mempunyai daya tarik dan menyentuh perasaan yang disampaikan kepada anak secara lisan atau tertulis. Metode bercerita juga merupakan suatu metode dalam aspek pengembangan bahasa yang bertujuan meningkatkan keterampilan menyimak, karena melalui metode bercerita anak dapat pengetahuan, melatih anak untuk berkomunikasi dan menjadikan anak senang dalam mengikuti pembelajaran.

Berdasarkan hal tersebut, peneliti tertarik untuk melakukan penelitian yang berjudul "Meningkatkan Keterampilan Menyimak pada Anak Usia Dini Melalui Metode Bercerita". Tujuan yang ingin dicapai dalam penelitian ini adalah untuk meningkatkan keterampilan menyimak anak dengan menggunakan metode bercerita pada kelompok B1 RA Persis 250 Cihamerang.

\section{Metodologi}

Penelitian ini dilaksanakan di RA Persis 250 Cihamerang Banjaran Kabupaten Bandung. Penelitian ini dilakukan di kelompok B1 RA Persis 250 Cihamerang pada semester I Tahun Ajaran 2018/2019. Waktu penelitian dimulai bulan September sampai bulan Oktober. Subjek penelitian berjumlah 20 anak terdiri dari 10 anak laki-laki dan 10 anak perempuan.

Pendekatan dalam penelitian ini menggunakan pendekatan penelitian kualtatif dan kauntitatif atau disebut dengan pendekatan campuran (mixed method). Sebagaimana pendapat dari Sugiyono (2016) bahwa penelitian campuran (mixed method) merupakan metode yang mengkombinasikan atau menggabungkan antara metode kuantitatif dan kualitatif untuk 
digunakan secara bersama-sama dalam suatu kegiatan penelitian, sehingga diperoleh data yang lebih komprehenshif, valid, reliable, dan objektif.

Metode yang digunakan dalam penelitian ini adalah metode penelitian tindakan kelas. Dalam penelitian ini, peneliti diposisikan bukan sekedar untuk memecahkan masalah pembelajaran yang ada di dalam kelas tetapi juga merefleksikan secara kritis dan kolaboratif suatu rencana pembelajaran. Penelitian tindakan kelas secara prosedur biasanya meliputi beberapa siklus yang disesuaikan dengan tingkat permasalahan yang akan dipecahkan dan kondisi yang akan ditingkatkan (Mulyasa, 2011).

Penelitian ini dilakukan secara bersiklus yang terdiri dari proses perencanaan (planning), pelaksanaan (acting), observasi (observing), dan refleksi (reflecting). Kegiatan ini sesuai dengan model penelitian tindakan kelas yang dikemukakan Kemis \& Taggart. Hubungan keempat komponen tersebut dipandang sebagai siklus yang dapat dijelaskan sebagai berikut: (1) Perencanaan, pada tahap ini peneliti menyusun jadwal penelitian, menyiapkan RPPH, menyiapkan instrumen, serta menyiapkan alat dan bahan yang dibutuhkan dalam penelitian. (2) Pelaksanaan, tahapan ini peneliti berkolaborasi dengan guru melaksanakan suatu proses kegiatan bercerita sesuai dengan apa yang sudah direncanakan. (3) Pengamatan, tahapan ini peneliti dan guru melakukan pengamatan dan pencatatan terhadap gejala-gejala yang tampak terjadi selama proses kegiatan berlangsung. (4) Refleksi, merupakan diskusi antara peneliti dan guru kelas yang bersangkutan untuk mengevaluasi hasil tindakan yang dilakukan.

Jenis data dalam penelitian ini adalah data kualitatif dan kuantitatif. Menurut Arikunto (2015) data kualitatif merupakan data yang berbentuk kalimat, kata atau gambar sedangkan data kuantitataif adalah data yang terkumpul dan dianalisis dengan menggunakan statistik deskriptif sehingga dapat disimpulkan hipotesis yang dirumuskan terbukti atau tidak.

Dalam melaksanakan pengumpulan data, peneliti menggunakan beberapa alat yang digunakan yaitu observasi, unjuk kerja, dan dokumentasi. Observasi merupakan teknik pengumpulan data dengan cara mengamati setiap kejadian yang sedang berlangsung dan mencatatnya dengan alat observasi tentang hal-hal yang akan diamati atau diteliti (Sanjaya, 2015: 86). Unjuk kerja merupakan teknik pengumpulan data berupa penilaian yang menuntut anak didik untuk melakukan tugas dalam perbuatan yang diamati (Uyu, dkk., 2012). Dokumentasi menurut Sugiyono (2016) merupakan catatan peristiwa yang sudah berlalu, bisa berbentuk tulisan, gambar, dan foto.

Analisis data yang dilakukan dalam penelitian ini terbagi dalam dua bagian berikut. 
1. Analisis pengamatan observasi, analisis hasil pengamatan digunakan untuk mengetahui aktivitas guru dan anak selama kegiatan bercerita menggunakan data berupa hasil lembar observasi yang dianalisis menggunakan data deskriptif kualitatif dengan menggunakan rumus:

$$
\mathrm{NP}=\frac{R}{S M} \mathrm{X} 100 \% \quad \text { (Purwanto, 2017) }
$$

Keterangan:

NP : Nilai Presentase aktivitas yang dicapai/dicari

R : Skor mentah yang diperoleh

SM : Skor maksimum ideal

Nilai aktivitas yang diperoleh melalui rumus di atas, selanjutnya diinterpretasikan pada skala kualifikasi yang dikemukakan oleh Purwanto (2017) yaitu:

Tabel 1 Skala Kualifikasi Penilaian Pembelajaran

\begin{tabular}{ccc}
\hline No & Tingkat Penguasaan & Predikat \\
\hline 1. & $86-100 \%$ & Sangat Baik \\
2. & $76-85 \%$ & Baik \\
3. & $60-75 \%$ & Cukup \\
4. & $55-59 \%$ & Kurang \\
5. & $\leq-54 \%$ & Kurang Sekali \\
\hline
\end{tabular}

2. Perhitungan keterampilan menyimak, baik sebelum maupun setelah diterapkan metode bercerita melalui rumus sebagai berikut:

$$
\mathrm{KM}=\frac{\text { Skor perolehan anak }}{\text { skor maksimal }} \times 100 \quad \text { (Hayati. 2014) }
$$

Keterangan:

KM : Keterampilan Menyimak

Setelah diperoleh nilai atau skor keterampilan menyimak setiap anak, kemudian diinterpretasikan pada skala kualifikasi kemampuan, sebagai berikut:

Tabel 2 Interval dan Hasil Belajar

\begin{tabular}{ccc}
\hline No & Tingkat Penguasaan & Predikat \\
\hline 1. & $80-100$ & Sangat Baik \\
2. & $70-79$ & Baik \\
3. & $60-69$ & Cukup \\
4. & $50-59$ & Kurang \\
5. & $0-54$ & Kurang Sekali \\
\hline \multicolumn{3}{c}{ Sumber: Syah (2015) }
\end{tabular}




\section{Hasil dan Diskusi}

Sebelum melakukan kegiatan pembelajaran menggunakan metode bercerita, peneliti terlebih dahulu melakukan kegiatan pra siklus yang dilakukan untuk mendapat data awal anak sebelum diterapkan metode bercerita. Peneliti sebagai pelaksana pembelajaran dan guru sebagai observer melakukan pra siklus pada hari Selasa, tanggal 25 September 2018.

Teknik pengumpulan data yang digunakan untuk mengetahui keterampilan menyimak anak pada pra siklus ini yaitu menggunakan teknik unjuk kerja dengan menggunakan metode mendongeng. Hasil unjuk kerja anak-anak di kelas B1 RA Persis 250 Cihamerang, menunjukkan bahwa sebagian besar anak masih mengalami kesulitan.

Keterampilan menyimak anak di kelas B1 RA Persis 250 Cihamerang Banjaran Kabupaten Bandung sebelum diterapkan metode bercerita (pra siklus), diukur melalui instrumen unjuk kerja yang terdiri dari 6 pernyataan, yaitu: anak dapat mendengarkan guru mendongeng; (2) anak dapat menirukan suara tokoh dalam dongeng; (3) anak dapat menyebutkan tokoh dalam dongeng; (4) anak dapat menyebutkan jumlah tokoh dalam dongeng; (5) anak dapat menyebutkan judul dongeng; dan (6) anak dapat menceritakan kembali isi dongeng. Hasil unjuk kerja keterampilan menyimak anak pada pra tindakan diperoleh nilai rata-rata sebesar 32,29 dengan kriteria kurang sekali.

Adapun penerapan metode bercerita untuk meningkatkan keterampilan menyimak anak pada Kelompok B1 RA Persis 250 Cihamerang Banjaran Kabupaten Bandung yaitu pada siklus I penerapan metode bercerita untuk meningkatkan keterampilan menyimak anak dilakukan melalui aktivitas guru dan anak yang terdiri dari 2 tindakan. Berikut gambaran aktivitas guru dan anak selama pembelajaran.

Siklus I, tindakan pertama dilaksanakan pada hari Rabu tanggal 26 September 2018 dan tindakan kedua dilaksanakan pada hari Kamis tanggal 27 September 2018. Secara rinci empat tahap tersebut diuraikan sebagai berikut:

1. Perencanaan

Kegiatan yang dilakukan pada tahap perencanaan dapat diuraikan sebagai berikut.

a. Menyusun (RPPH) yang berkaitan dengan materi pembelajaran tentang keterampilan menyimak dengan menggunakan metode bercerita

b. Menetapkan meteri atau bahan ajar

c. Menyusun skenario pembelajaran dengan menggunakan metode bercerita yang akan diterapkan dalam pembelajaran 
d. Menyiapkan media pembelajaran yang terdiri dari buku cerita "Si Kembar dan Raja Nasi" pada tindakan pertama dan cerita "Aku suka Buah" pada tindakan kedua

e. Menyusun alat evaluasi berupa lembar observasi aktivitas anak dan observasi aktivitas guru serta lembar unjuk kerja anak untuk mengetahui perkembangan keterampilan menyimak anak

2. Pelaksanaan Tindakan

Pelaksanaan pembelajaran kegiatan bercerita pada tindakan pertama dilakukan pada hari Selasa tanggal 25 September 2018 dan tindakan kedua pada hari kamis tanggal 27 September 2018.Materi pada tindakan pertama yaitu cerita "Si Kembar dan Raja Nasi" dan pada tindakan kedua yaitu cerita "Aku suka Buah". Tema pada tindakan pertama yaitu Diri Sendiri sub tema Makanan.

Pada kegiatan awal peneliti mengawali kegiatan dengan mengajak anak untuk berbaris, mengucapkan salam, bernyanyi,berdo'a dan menanyakan hari. Kemudian peneliti menyapa anak dan menanyakan kesiapan mereka untuk memulai pembelajaran. Pada kegiatan inti peneliti menjelaskan tentang apa saja kegiatan yang dilakukan pada hari itu. Kegiatan dimulai dengan menyampaikan cerita "Si Kembar dan Raja Nasi” dan cerita "Aku suka Buah", selanjutnya peneliti menirukan suara tokoh, menyebutkan tokoh dan jumlah tokoh, menyebutkan judul cerita dan menyampaikan isi cerita.

Setelah kegiatan bercerita selesai, peneliti yang dibantu guru pendamping memberikan kesempatan kepada anak secara bergantian satu persatu untuk menirukan suara tokoh, menyebutkan tokoh dan jumlah tokoh, menyebutkan judul cerita dan menyampaikan isi dalam cerita yang telah disampaikan.Pada saat kegiatan mengajar, observer menilai aktivitas guru dan aktivitas anak selama kegiatan bercerita berlangsung serta kemampuan unjuk kerja mengenai keterampilan menyimak.Setelah itu kegiatan istirahat peneliti membimbing anak untuk berdo'a sebelum makan. Pada kegiatan penutup guru membimbing anak berdo'a setelah makan, dan membimbing anak berdo'a untuk pulang dan mengucapkan salam.

3. Observasi

Hasil observasi aktivitas guru pada tindakan pertama 68,75\%dengan kriteria cukup dan pada tindakan kedua ialah 75\% dengan kriteria baik mengalami peningkatan, maka rata-rata aktivitas guru sebesar $71,88 \%$ dengan kriteria cukup. Dengan demikian pembelajaran dilanjutkan pada siklus berikutnya.Adapun hasil observasi aktivitas anak pada siklus I mengalami peningkatan dengan rincian pada siklus I tindakan pertama 
diperoleh nilai rata-rata 59,39\% dengan kategori kurang sekali dan siklus I tindakan kedua diperoleh nilai rata-rata 64,38\% dengan kriteria cukup dengan rata-rata sebesar 61,88\% dengan kriteria cukup. Dengan demikian pembelajaran dilanjutkan ke siklus berikutnya.

Siklus II, terdiri dari 2 tindakan, tindakan pertama pada hari Senin tanggal 1 Oktober 2018 dan tindakan kedua dilaksanakan pada hari Rabu tanggal 3 Oktober 2018. Tindakan yang dilaksanakan pada siklus II ini mengacu pada hasil refleksi I, kekurangan yang terdapat pada siklus I diperbaiki pada siklus II sehingga untuk meningkatkan keterampilan menyimak dengan menggunakan metode bercerita dapat meningkat. Secara lebih rinci empat tahapan tersebut dapat diuraikan sebagai berikut.

1. Perencanaan

Kegiatan yang dilakukan pada tahap perencanaan pada siklus ini mengacu pada hasil refleksi dari siklus I. Perencanaan tersebut terdiri dari

a. Memperbaiki kembali Rencana Pelaksanaan Pembelajaran Harian (RPPH) yang disiapkan pada siklus II dengan melakukan revisi pada siklus I terutama dengan pengaturan waktu.

b. Mempersiapkan lembar observasi aktivitas guru, aktivitas anak dan lembar unjuk kerja.

c. Menyiapkan media buku Cerita "Koko si Brokoli Kribo" dan cerita "Aku suka Minum Susu” dengan menggunakan alat peraga pendukung dalam bercerita yaitu brokoli, susu kotak dan susu sachet, untuk menambah variasi tokoh dalam menyampaikan isi cerita yang diharapkan anak lebih senang dalam mengikuti kegiatan bercerita.

d. Mempersiapkan lembar unjuk kerja yang digunakan untuk mengetahui perkembangan keterampilan menyimak anak

2. Pelaksanaan Tindakan

Pelaksanaan penerapan metode bercerita untuk meningkatkan keterampilan menyimak anak pada siklus II tindakan pertama dilaksanan pada hari Senin tanggal 1 Oktober 2018 dan hari Rabu tanggl 3 Oktober 2018. Tema pada tindakan pertama yaitu Diri Sendiri sub tema Makanan. Materi pada tindakan pertama yaitu cerita "Koko si Brokoli Kribo" dengan menggunakan alat peraga asli yaitu brokoli, kegiatan bercerita untuk meningkatkan keterampilan menyimak anak dan cerita "Aku suka Minum susu 
dengan alat peraga asli yaitu susu sachet dan susu kotak, mengacu pada rencana pelaksanaan pembelajaran yang telah dibuat pada perencanaan siklus II.

Pada kegiatan awal pembelajaran anak melakukan kegiatan outdoor seperti biasanya, setelah itu anak mulai berbaris dan masuk ke ruangan kelas. Guru mengajak anak untuk bernyanyi dan memberisalam, berdo'a sebelum belajar, menanyakan hari dan menanyakan kabar serta menanyakan kesiapan mereka untuk mendengarkan cerita. Kegiatan dimulai dengan tanya jawab menggunakan alat peraga sayur-sayuran yaitu menggunakan alat peraga brokoli dan alat peraga susu sachet dan susu kotak, setelah itu anak minum susu bersama di kelas. Setelah itu guru bercerita "Koko si Brokoli Kribo" dan cerita "Aku suka Minum Susu" kemudian guru menyampaikan cerita, menirukan suara tokoh, menyebutkan tokoh dan jumlah tokoh, menyebutkan judul cerita dan menyampaikan isi cerita.

Setelah kegiatan bercerita selesai, peneliti dibantu guru pendamping memberikan kesempatan kepada anak secara bergantian satu persatu untuk, menirukan suara tokoh, menyebutkan tokoh dan jumlah tokoh, menyebutkan judul cerita dan menyampaikan isi dalam cerita yang telah disampaikan.Pada saat kegiatan pembelajaran, observer menilai tentang aktivitas guru dan aktivitas anak selama kegiatan pembelajaran menggunakan metode bercerita.Setelah itu pada kegiatan istirahat guru membimbing anak berdo'a sebelum dan sesudah makan.Pada kegiatan evaluasi guru mengulang kembali cerita yang telah disampaikan dan mengulang pertanyaan kepada anak. Kemudian pada kegiatan penutup guru membimbing anak berdo'a, membimbing anak untuk pulang dan mengucapkan salam.

3. Observasi

Pada siklus II penerapan metode bercerita mengalami peningkatan dapat dilakukan melalui observasi aktivitas guru dan anak yang terdiri dari dua tindakan setiap siklusnya. Hasil aktivitas guru pada siklus II mengalami peningkatan dengan rincian pada siklus II tindakan pertama 81,25\% dengan kategori baik dan siklus II tindakan kedua diperoleh nilai 100\% dengan kategori baik sekali dengan rata-rata sebesar 90,63\% dengan kriteria sangat baik. Maka dapat dikatakan aktivitas guru pada siklus II mengalami peningkatan dari siklus sebelumnya. Gambaran peningkatan hasil observasi aktivitas guru dari siklus I sampai siklus II dapat dilihat berikut ini. 


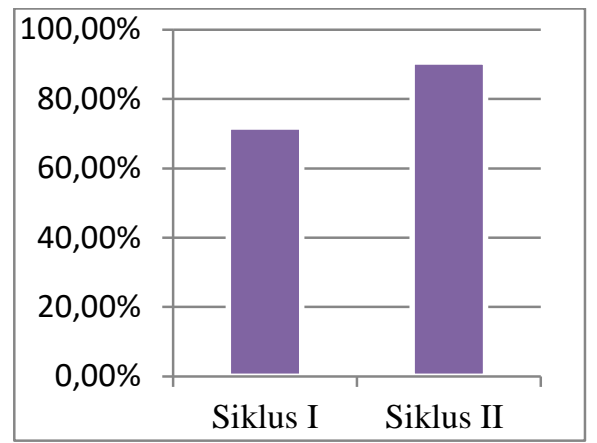

Gambar 2. Peningkatan Aktivitas Guru

Adapun hasil observasi aktivitas anak pada siklus II mengalami peningkatan dengan rincian pada siklus II tindakan pertama diperoleh nilai sebesar 69,81\% dengan kategori cukup dan siklus II tindakan kedua diperoleh nilai 85,93\% dengan kategori baik, dengan rata-rata sebesar 77,88\% dengan kriteria baik. Maka terjadi peningkatan dari siklus I yang mendapat kriteria cukup ke siklus II yang mendapat kriterai baik. Gambaran peningkatan hasil observasi aktivitas anak dari siklus I sampai siklus II dapat dilihat berikut ini.

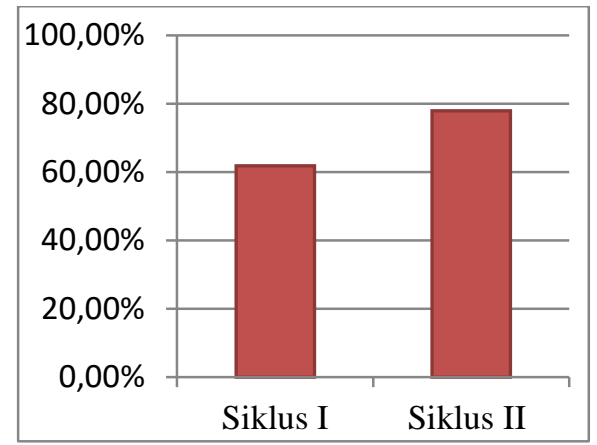

Gambar 3. Peningkatan Aktivitas Anak

Keterampilan menyimak setelah diterapkan metode bercerita pada kelompok B1 RA Persis 250 Cihamerang Banjaran Kabupaten Bandung pada siklus I keterampilan menyimak anak setelah diterapkan metode bercerita melalui unjuk kerja pada siklus I tindakan pertama diperoleh nilai sebesar 43,75 dan tindakan kedua diperoleh nilai sebesar 61,67 dengan ratarata sebesar 52,71 dengan kategori kurang.

Pada siklus II tindakan pertama diperoleh nilai sebesar 70,21 dan tindakan kedua diperoleh nilai sebesar 86,67 dengan rata-rata sebesar 78,44 dengan kategori baik. Dengan demikian hipotesis yang diajukan diterima, artinya metode bercerita dapat meningkatkan keterampilan menyimak anak.

Perbandingan peningkatan kemampuan kognitif anak pada pembelajaran sains pra siklus, siklus I dan siklus II dapat digambarkan sebagai berikut. 


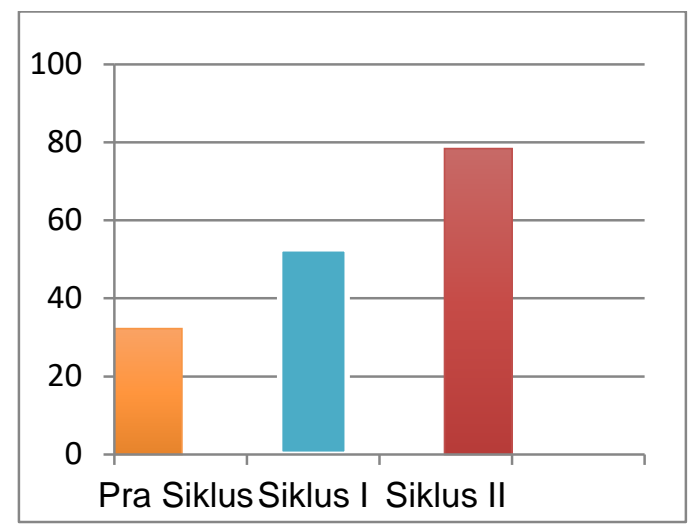

Gambar 4. Grafik Peningkatan Keterampilan Menyimak Anak

Pada pra siklus keterampilan menyimak anak diperoleh sebesar 32,29 dengan kriteria kurang sekali. Hal ini menunjukkan bahwa keterampilan menyimak masih rendah. Menurut Permendiknas No. 58 menyebutkan bahwa keterampilan menyimak yang seharusnya sudah dikuasai anak usia 4-5 tahun meliputi menyimak perkataan orang, memahami cerita yang dibacakan, dan menceritakan kembali cerita yang pernah didengar.

Keterampilan menyimak sangat penting bagi perkembangan anak, hal ini sesuai menurit pendapat Dhienie (2008) bahwa menyimak berperan sebagai dasar belajar bahasa, penunjang keterampilan berbicara, membaca dan menulis, menunjang komunikasi lisan, dan menambah informasi/pengetahuan.Sedangkan menurut Iskandarwassid, dkk, (2011) keterampilan menyimak sangat penting bagi anak, karena kebanyakan orang dewasa dalam aktivitas komunikasi 45\% digunakan untuk menyimak, 30\% untuk berbicara, 16\% untuk membaca dan hanya $9 \%$ untuk menulis.

Dalam proses pembelajaran keterampilan menyimak diperlukan metode yang tepat dan yang menarik perhatian anak salah satunya menggunakan metode bercerita. Hal ini sesuai dengan pendapat Gunarti (2008) bahwa metode bercerita merupakan salah satu metode dalam aspek pengembangan bahasa yang bertujuan untuk meningkatkan keterampilan menyimak, karena melalui metode bercerita anak bisa bercerita bebas dan mengemukakan ide-idenya, menyampaikan informasi, mempunyai daya tarik anak yang menyentuh persaan anak dan memahami pesan yang bisa dilakukan secara lisan atau tertulis.

Dalam pelaksanaan keterampilan menyimak hal pertama yang dilakukan oleh guru adalah membacakan cerita kepada anak. Kemudian guru mengajak anak untuk menjawab pertanyaan dari guru. Hal ini terlihat ketika anak mendengarkan guru bercerita, menjawab judul cerita, menirukan suara tokoh, menyebutkan jumlah dan tokoh dalam cerita, dan menyebutkan isi dalam cerita. Setelah anak menjawab pertanyaan dengan berulang-ulang dari 
guru anak terbiasa medengarkan perintah dari guru. Setelah melakukan kegiatan bercerita, anak-anak kelompok B1 RA Persis 250 Cihamerang Banjaran Kabupaten Bandung mengalami peningkatan dalam hal keterampilan menyimak. Hal ini terlihat dari keterampilan anak dalam menceritakan kembali isi cerita, menyebutkan jumlah dan tokoh, menirukan suara tokoh, menjawab judul cerita, dan mendengarkan guru bercerita. Selain itu, kepercayaan diri anak meningkat setelah diterapkan metode bercerita.Anak yang biasanya hanya diam tidak mudah bersosialisasi dengan teman-temannya, setelah diterapkan metode bercerita anak menjadi lebih percaya diri dan mau ikut berbicara dengan teman-temannya.

Selain hasil yang dicapai, keberhasilan lain juga dilihat dari keadaan anak-anak yang sangat percaya diri untuk berkomunikasi dan bersosialisasi dengan teman-temannya. Metode bercerita merupakan metode yang disampaikan guru kepada anak secara lisan dalam bentuk cerita, yang pada dasarnya disukai oleh anak-anak. Untuk itu keterampilan menyimak pada anak perlu diperkaya dengan inovasi-inovasi agar anak antusias dalam mengikutinya. Dengan melalui aspek perkembangan bahasa anak akan terlibat langsung pada pengalaman yang dapat melatih imajinasi anak yang dapat berkembang sesuai harapan.

\section{Penutup}

Berdasarkan analisis data tentang penerapan metode bercerita untuk meningkatkan keterampilan menyimak anak yang dilakukan di RA Persis 250 Cihamerang. Keterampilan menyimak pada anak di kelompok B1 RA Persis 250 Cihamerang Banjaran Kabupaten Bandung sebelum menggunakan metode bercerita dengan kriteria kurang sekali. Proses penerapan metode bercerita dalam meningkatkan keterampilan menyimak sudah tergolong dalam kriteria baik. Hal ini terlihat dari pelaksanaan semua tahapan penerapan metode bercerita oleh guru dan anak. Aktivitas guru dan anak mengalami peningkatan pada setiap siklusnya. Aktivitas guru pada siklus I pada kriteria cukup dan pada siklus II keterlaksanaan aktivitas guru sangat baik. Aktivitas anak pada siklus I dengan kriteria cukup, dan pada siklus II observasi aktivitas anak dengan kriteria baik. Keterampilan menyimak setelah diterapkan metode bercerita pada setiap siklusnya mengalami peningkatan. Hal ini dapat dilihat dari meningkatnya keterampilan menyimak melalui unjuk kerja pada siklus I dengan kriteria kurang, dan pada siklus II dengan kriteria baik.

Berdasarkan kesimpulan di atas ada beberapa saran yang ingin peneliti uraikan yaitu: (1) Dalam merencanakan kegiatan pembelajaran yang berhubungan dengan keterampilan 
menyimak, hendaknya dibuat kegiatan yang menarik perhatian sehingga anak aktif dalam pembelajaran, salah satu cara yang membuat anak aktif dan membuat anak senang yaitu dengan menggunakan metode bercerita. (2) Dalam kegiatan bercerita guru harus dapat mengatur dan mengalokasikan waktu dengan baik karena dalam penerapan kegiatan pebelajaran ini memerlukan waktu yang cukup efektif dan efisien, sehingga jika tanpa bimbingan dari guru maka pebelajaran tidak akan mencapai hasil yang maksimal. (3) Setelah diterapkan metode bercerita anak yang sudah dapat menyimak cerita dari guru sebaiknya anak dapat bercerita sendiri di kelas dengan menggunakan bahasanya sendiri. Hal tersebut ditujukan untuk meningkatkan keterampilan menyimak setiap anak. Keteramilan menyimak sangat penting bagi perkembangan bahasa, oleh karena itu peneliti selanjutnya diharapkan dapat membuat penelitian mengenai keterampilan menyimak melalui kegiatan lain yang lebih menarik bagi anak.

\section{Daftar Pustaka}

Arikunto. (2015). Penelitian Tindakan Kelas. Jakarta: Bumi Aksara.

Dhienie, dkk. (2008). Metode Pengembangan Bahasa. Jakarta: Universitas Terbuka.

Gunarti. (2008). Metode Pengembangan Perilaku dan Kemampuan Dasar Anak Usia Dini. Jakarta: Universitas Terbuka.

Hayati, T. (2014). Evaluasi Pembelajaran. Bnadung: CV. Insan Mandiri.

Iskandarwassid, dkk. (2008). Strategi Pembelajaran Bahasa. Bandung: Rosdakarya

Latifah, S. (2011). Kurikulum Raudhatul Athfal. Bandung: IGRA.

Mulyasa. (2009). Praktek Penelitian Tindakan Kelas. Bandung: Rosdakarya.

Moeslichatoen. (2004). Metode Pengajaran di Taman Kanak-Kanak. Bandung: Rineka Cipta

Permendiknas No 58 Tahun 2009 tanggal 17 September Tentang Standar Pendidikan Anak Usia Dini.

Purwanto, N. (2007). Prinsip-Prinsip Evaluasi Pendidikan. Bandung: Rosdakarya.

Sanjaya, W. (2009). Penelitian Tindakan Kelas. Jakarta: Kencana.

Sugiyono. (2016). Metode Penelitian Pendidikan.Bandung: ALFABETA.

Sujiono. (2013). Konsep Dasar Pendidikan Anak Usia Dini. Jakarta: Indeks.

Tarigan. (2015). Menyimak Sebagai Suatu Keterampilan Berbabasa. Bandung: ANGKASA.

Uyu, dkk. (2011). Penilaian Perkembangan Anak Usia Dini. Bandung: Refika Aditama. 